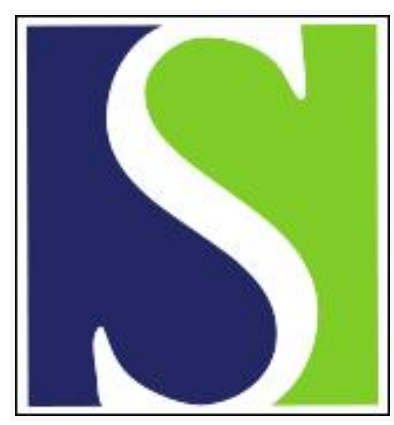

Scand J Work Environ Health 1994;20(5):331-338

https://doi.org/10.5271/sjweh.1389

Issue date: 01 Oct 1994

\title{
Mortality of filling station attendants.
}

by Lagorio S, Forastiere F, lavarone I, Rapiti E, Vanacore N, Perucci CA, Carere A

Affiliation: National Health Institute, Rome, Italy.

This article in PubMed: www.ncbi.nlm.nih.gov/pubmed/7863296 


\title{
Mortality of filling station attendants
}

\author{
by Susanna Lagorio, MD, ${ }^{1}$ Francesco Forastiere, $\mathrm{PhD},{ }^{2}$ Ivano lavarone, DSc, ${ }^{1}$ \\ Elisabetta Rapiti, MD, ${ }^{2}$ Nicola Vanacore, $\mathrm{BSc},{ }^{3}$ Carlo Alberto Perucci, MD, ${ }^{2}$ Angelo Carere $\mathrm{PhD}^{1}$
}

\author{
LAGORIO S, FORASTIERE F, IAVARONE I, RAPITI E, VANACORE N, PERUCCI CA, CARERE \\ A. Mortality of filling station attendants. Scand $J$ Work Environ Health 1994;20:331 -8.
}

OвJеctives - Gasoline contains established human carcinogens, such as benzene. The health impact of exposure to this fuel, however, has not been fully elucidated. We report on the mortality of a cohort of 2665 filling station managers from the Latium region (Italy).

METHODS - This is the first workplace-based cohort of gas station attendants. However, only selfemployed individuals were available for study (about $50 \%$ of the whole work force). The follow-up period extended from 1981 through 1992. The mortality experience of the cohort was compared with that of the regional population.

Results - The overall analysis for standardized mortality ratios (SMR) showed a significantly decreased mortality from all causes, mainly due to a deficit of cardiovascular diseases and malignant neoplasms. Nonsignificantly increased risks for esophageal cancer [SMR 241, $90 \%$ confidence interval (90\% CI) 82-551], brain cancer (SMR 195, 90\% CI 77-401) and non-Hodgkin's lymphoma (SMR 173, 90\% CI 47-448) were found for the men; mortality due to lung cancer and leukemia was lower than expected, and no kidney cancer death was recorded. Among the attendants of small stations (characterized by a small number of employees and high sales of gasoline per full-time employee), the SMR values for esophageal cancer (for men SMR 351, 90\% CI 120-803) and brain cancer (for men and women SMR 266, 90\% CI 105-559) showed increased values.

Conclusions - Filling station attendants are exposed to gasoline vapors and seem at risk of cancer of various sites. Due to the power limitations of this study, however, a precise estimate of the risk for many causes of death was not achievable. Further cohort studies of greater size are warranted.

KEY TERMS - benzene, cohort, gasoline exhausts, gasoline vapors, occupational cancer.

Gasoline is a complex and highly variable mixture of aliphatic and aromatic hydrocarbons, mainly of low molecular weight (1). Exposures to gasoline fuel and to exhausts from engines operating on gasoline are considered by the International Agency for Research on Cancer as possibly carcinogenic to humans $(2-3)$.

So far, however, the health impact of exposure to petroleum fuels has not been fully elucidated (4). In particular, the hazard posed by exposure to benzene via gasoline vapors and exhausts is of major concern, due to the great number of workers employed in petroleum distribution trades and to the relevant contribution of such sources to the pollution burden in urban environments $(5,6)$.

While in the United States and northern Europe self-service stations dominate, Italy and other southern European countries still employ large numbers of workers in gasoline retail trades. In this paper we

I National Health Institute, Rome, Italy.

2 Epidemiological Unit, Latium Regional Health Authority, Rome, Italy.

3 Department of Neurology, "La Sapienza" University, Rome, Italy.

Reprint requests to: Dr S Lagorio, Istituto Superiore di Sanità, Laboratorio di Igiene Ambientale, Viale Regina Elena 299, I-00161 Rome, Italy. describe the mortality experience of a cohort of filling station attendants from a region of central Italy.

\section{Subjects and methods}

\section{Cohort design}

A nationwide survey of service stations was carried out in Italy in 1980. Information on several characteristics of the stations and their managers was collected during the survey, such as the name, date of birth and length of employment of the manager, the number of attendants, the quantity of fuel sold in the previous four years, and the number of fuel deliveries to the station per year. Detailed data for the Latium region (central Italy) were obtained, and managers who were clearly identifiable as individuals (as opposed to commercial houses) and who were still alive on 1 January 1981 were considered eligible for the study [2665 stations and managers out of 3272 original records $(81.4 \%)$ ].

The cohort consisted of 2665 service station managers ( 2308 men and 357 women). At entry into the study their age averaged 46 years, their mean length of employment was 14 years, and most of them $(91 \%)$ were full-time employees (table 1). At the end of the study, 2236 subjects were still alive $(84 \%)$, 270 had died $(10 \%)$, and 159 had not been traced 
Table 1. Distribution of filling station attendants by gender according to age and length of employment at entry, worktime, vital status at the end of the follow-up, and person-years of observation.

\begin{tabular}{|c|c|c|c|c|c|c|}
\hline & \multicolumn{2}{|c|}{ Men } & \multicolumn{2}{|c|}{ Women } & \multicolumn{2}{|c|}{ Total } \\
\hline & $\mathbf{N}$ & $\%$ & $\mathrm{~N}$ & $\%$ & $N$ & $\%$ \\
\hline \multicolumn{7}{|l|}{ Age at entry (years) } \\
\hline $\begin{array}{l}19-24 \\
25-34 \\
35-44 \\
45-54 \\
\geq 55\end{array}$ & $\begin{array}{r}67 \\
334 \\
632 \\
704 \\
571\end{array}$ & $\begin{array}{r}2.9 \\
14.5 \\
27.4 \\
30.5 \\
24.7\end{array}$ & $\begin{array}{r}11 \\
62 \\
90 \\
102 \\
92\end{array}$ & $\begin{array}{r}3.1 \\
17.4 \\
25.2 \\
28.6 \\
25.8\end{array}$ & $\begin{array}{r}78 \\
396 \\
722 \\
806 \\
663\end{array}$ & $\begin{array}{r}2.9 \\
14.9 \\
27.1 \\
30.2 \\
24.9\end{array}$ \\
\hline Total & 2308 & 100.0 & 357 & 100.0 & 2665 & 100.0 \\
\hline \multicolumn{7}{|c|}{$\begin{array}{l}\text { Length of employment } \\
\text { at entry (years) }\end{array}$} \\
\hline $\begin{array}{l}1-10 \\
11-20 \\
\geq 21\end{array}$ & $\begin{array}{l}863 \\
897 \\
439\end{array}$ & $\begin{array}{l}39.2 \\
40.8 \\
20.0\end{array}$ & $\begin{array}{r}210 \\
85 \\
34\end{array}$ & $\begin{array}{l}63.8 \\
25.8 \\
10.3\end{array}$ & $\begin{array}{r}1073 \\
982 \\
473\end{array}$ & $\begin{array}{l}42.4 \\
38.8 \\
18.7\end{array}$ \\
\hline \multicolumn{7}{|l|}{ Worktime } \\
\hline $\begin{array}{l}\text { Full-time } \\
\text { Part-time }\end{array}$ & $\begin{array}{r}1941 \\
157\end{array}$ & $\begin{array}{r}92.5 \\
7.5\end{array}$ & $\begin{array}{r}228 \\
53\end{array}$ & $\begin{array}{l}81.1 \\
18.9\end{array}$ & $\begin{array}{r}2169 \\
210\end{array}$ & $\begin{array}{r}91.2 \\
8.8\end{array}$ \\
\hline \multicolumn{7}{|l|}{ Vital status } \\
\hline $\begin{array}{l}\text { Alive } \\
\text { Deceased } \\
\text { Lost to follow-up }\end{array}$ & $\begin{array}{r}1922 \\
250 \\
136\end{array}$ & $\begin{array}{r}83.3 \\
10.8 \\
5.9\end{array}$ & $\begin{array}{r}314 \\
20 \\
23\end{array}$ & $\begin{array}{r}88.0 \\
5.6 \\
6.4\end{array}$ & $\begin{array}{r}2236 \\
270 \\
159\end{array}$ & $\begin{array}{r}83.9 \\
10.1 \\
6.0\end{array}$ \\
\hline \multicolumn{7}{|l|}{ Person-years by age } \\
\hline $\begin{array}{l}\leq 29 \\
30-39 \\
40-49 \\
50-59 \\
60-69 \\
\geq 70\end{array}$ & $\begin{array}{r}785 \\
3487 \\
6617 \\
7228 \\
4252 \\
1664\end{array}$ & $\begin{array}{r}3.3 \\
14.5 \\
27.5 \\
30.1 \\
17.7 \\
6.9\end{array}$ & $\begin{array}{r}113 \\
622 \\
1020 \\
1113 \\
706 \\
291\end{array}$ & \begin{tabular}{r|}
2.9 \\
16.1 \\
26.4 \\
28.8 \\
18.3 \\
7.5
\end{tabular} & $\begin{array}{r}898 \\
4109 \\
7637 \\
8341 \\
4958 \\
1954\end{array}$ & $\begin{array}{r}3.2 \\
14.7 \\
27.4 \\
30.0 \\
17.8 \\
7.0\end{array}$ \\
\hline Total & 24033 & 100.0 & 3864 & 100.0 & 27897 & 100.0 \\
\hline
\end{tabular}

Table 2. Characteristics of the 2665 stations whose managers were enrolled in the cohort study, by station size.

\begin{tabular}{|c|c|c|c|c|c|c|c|c|}
\hline \multirow[b]{2}{*}{ Station size } & \multicolumn{2}{|c|}{$\begin{array}{l}\text { Yearly gasoline } \\
\text { sales }\end{array}$} & \multicolumn{2}{|c|}{$\begin{array}{l}\text { Capacity of under- } \\
\text { ground gasoline } \\
\text { tank }\end{array}$} & \multicolumn{2}{|c|}{$\begin{array}{l}\text { Number of } \\
\text { employees }\end{array}$} & \multicolumn{2}{|c|}{$\begin{array}{l}\text { Yearly gasoline sales } \\
\text { per full-time } \\
\text { employee }\end{array}$} \\
\hline & $\begin{array}{l}\text { Number } \\
\text { of } \\
\text { stations }\end{array}$ & $\begin{array}{l}\text { Mean } \\
\text { number of } \\
\text { liters }\end{array}$ & $\begin{array}{l}\text { Number } \\
\text { of } \\
\text { stations }\end{array}$ & $\begin{array}{l}\text { Mean } \\
\text { capacity } \\
\left(\mathrm{m}^{3}\right)\end{array}$ & $\begin{array}{l}\text { Number } \\
\text { of } \\
\text { stations }\end{array}$ & $\begin{array}{c}\text { Mean } \\
\text { number of } \\
\text { employees }\end{array}$ & $\begin{array}{l}\text { Number } \\
\text { of } \\
\text { stations }\end{array}$ & $\begin{array}{l}\text { Mean } \\
\text { number of } \\
\text { liters }\end{array}$ \\
\hline $\begin{array}{l}\text { Small } \\
\text { Large }\end{array}$ & $\begin{array}{r}1720 \\
911\end{array}$ & $\begin{array}{l}409605 \\
544099\end{array}$ & $\begin{array}{r}1738 \\
918\end{array}$ & $\begin{array}{r}9.64 \\
16.08\end{array}$ & $\begin{array}{r}1683 \\
898\end{array}$ & $\begin{array}{l}1.87 \\
2.95\end{array}$ & $\begin{array}{r}1659 \\
889\end{array}$ & $\begin{array}{l}264213 \\
218573\end{array}$ \\
\hline
\end{tabular}

$(6 \%)$. No information on the cause of death was available for 12 deceased persons (4\%).

Some characteristics of the 2665 service stations in 1980 are described in table 2 by station size. Large stations, as expected, had higher sales of gasoline, underground tanks of greater capacity, and a greater number of employees than the small stations. The latter, however, were characterized by significantly higher sales of gasoline per full-time employee.

Each subject was considered from 1 January 1981 through 31 July 1991 if resident in Rome at the time of entry into the study, or through 30 June 1992 if resident in any other municipality within the Latium region. Vital status was ascertained through the registry of the last municipality of residence. The code for the underlying cause of death in the International Classification of Diseases (ICD), IX revision, was retrieved by means of various methods, as described in detail elsewhere (7): first, through record linkage with the National Mortality File for deaths occurring before 1986; second, through record linkage with the Regional Death Index for deaths occurring during the period 1986 - 1992; third, from the registry of the municipality where the death occurred for those cases for which linkage procedures were unproductive. In the last case [ 75 out of 270 deceased individuals $(28 \%)$ ], the underlying cause of death was coded by an expert nosologist.

For the calculation of person-years at risk of dying, each subject was considered from 1 January 1981 until the end of the study period or the date of death. Those lost to follow-up were considered alive at the end of the study period. Standardized mortality ratios (SMR) and their $90 \%$ confidence intervals (90\% 
CI) were used to compare the mortality experience of the cohort with that of the regional population. The expected number of deaths was calculated with the use of gender-, age- and period-specific regional mortality rates. The statistical package OCMAP (8) was used for the analysis.

\section{Exposure assessment}

Information on duration of employment at entry, along with a series of indicators of work load, were available for all cohort members from the 1980 survey. No vapor recovery system has been enforced in Italy, and the relative quantity of fuel sold has remained relatively stable. Unleaded gasoline, in fact, still accounts for less than $5 \%$ of the total amount of marketed fuel. Due to the characteristics of Italian service stations, the yearly average quantity of gasoline sold per full-time employee can be considered an indicator of the average intensity of exposure experienced by the manager at refuelling.

Exposure to aromatic hydrocarbons among currently employed filling station workers was estimated by means of an environmental survey taken in 1992 (9). Measured concentrations of benzene, toluene, and xylenes [8-h time-weighted averages (TWA)] averaged $0.55,0.71$, and $0.32 \mathrm{mg} \cdot \mathrm{m}^{-3}$, respectively. The number of vehicles filled, the daily sales of super premium gasoline and motor-bike fuel, and the winter season were all significant predictors of the logarithmic concentration of benzene (8-h TWA) in the simple regression analyses. The size of the station acted as an exposure modifier. While no single variable was able to predict the benzene level in large stations, for small stations an increase of 0.0579 and 0.0418 in the $\log$ benzene concentration per unit of increase in super premium gasoline $(100 \mathrm{l})$ and in motor-bike fuel (10 1), respectively, was estimated. The overall variance explained by the multivariate model was, however, only $12.3 \%$. Therefore, a clearly defined categorization of the subjects into groups with internally homogeneous and significantly different exposure levels was not feasible. As regards the exposure assessment of the cohort, it seems that workers in small-size stations with higher sales of super premium gasoline may experience higher levels of exposure. We decided, consequently, to examine in detail this group of workers.

\section{Results}

All-cause mortality was significantly decreased, mainly due to a deficit in cardiovascular diseases and malignant neoplasms. The risk of blood disease (among both the men and the women) and injuries (only among the men) was increased, but the excess was not statistically significant (table 3 ).

Although cancer mortality was lower than expected, nonsignificantly increased risks were found for non-Hodgkin's lymphoma and for esophageal and nervous system cancers among the men (table 4). One case of soft-tissue sarcoma and one case of melanoma were observed versus 0.2 and 0.7 expected, respectively. The risk of colon and bladder cancers was slightly elevated, while mortality due to lung cancer and leukemia was lower than expected. No kidney cancer death was recorded, whereas two cases were expected. The number of deaths recorded among the women was very small ( 20 deaths, 5 cancers). Excess risks were found for pancreatic, uterine, and brain cancer, but each excess was based on one observed case (table 4).

Among the attendants of small stations, the SMR values for esophageal and brain cancer showed increased values when compared with the overall findings, reaching statistical significance among the men and in the whole subcohort. Moreover, the ex-

Table 3. Mortality of the service station attendants from the Latium region (1981-1992) by broad groups of causes of death. $(\mathrm{O}=$ observed deaths, $\mathrm{E}=$ expected deaths, $\mathrm{SMR}=$ standardized mortality ratio, $90 \% \mathrm{Cl}=90 \%$ confidence interval)

\begin{tabular}{|c|c|c|c|c|c|c|c|c|c|c|c|c|}
\hline \multirow{2}{*}{ Cause of deatha } & \multicolumn{4}{|c|}{ Men } & \multicolumn{4}{|c|}{ Women } & \multicolumn{4}{|c|}{ Total } \\
\hline & 0 & $E$ & SMR & $90 \% \mathrm{Cl}$ & 0 & $E$ & SMR & $90 \% \mathrm{Cl}$ & 0 & $E$ & SMR & $90 \% \mathrm{Cl}$ \\
\hline Infectious diseases $(001-009)$ & - & 1.8 & $\cdot$ & $\cdot$ & 1 & 0.1 & 769 & $39-3649$ & 1 & 1.9 & 52 & $3-247$ \\
\hline Malignant neoplasms (140-208) & 78 & 99.6 & 78 & $64-95$ & 5 & 8.9 & 56 & $22-119$ & 83 & 108.5 & 77 & $63-92$ \\
\hline $\begin{array}{l}\text { Benign and unspecified neoplasms } \\
(210-239)\end{array}$ & 1 & 1.3 & 77 & $4-365$ & - & 0.1 & . & · & 1 & 1.4 & 69 & $4-329$ \\
\hline Diabetes mellitus $(250)$ & $\overline{7}$ & 9.6 & 73 & $34-138$ & 1 & 1.5 & 67 & $3-316$ & 8 & 11.1 & 72 & $36-131$ \\
\hline Blood (280-289) & 1 & 0.8 & 127 & $6-601$ & 1 & 0.1 & 1111 & $57-5271$ & 2 & 0.9 & 227 & $40-715$ \\
\hline Nervous system $(320-359)$ & 4 & 4.4 & 92 & $31-210$ & - & 0.5 & $\cdot$ & $\cdot$ & 4 & 4.8 & 83 & $28-190$ \\
\hline Circulatory system $(390-459)$ & 97 & 114.7 & 85 & $71-210$ & 6 & 9.6 & 62 & $27-123$ & 103 & 124.3 & 83 & $70-98$ \\
\hline Respiratory system (460-519) & 14 & 19.4 & 72 & $44-113$ & - & 1.0 & $\cdot$ & $\cdot$ & 14 & 20.4 & 69 & $41-107$ \\
\hline Digestive system $(520-579)$ & 15 & 22.0 & 68 & $42-105$ & 3 & 1.5 & 200 & $55-517$ & 18 & 23.5 & 76 & $49-113$ \\
\hline Genitourinary system (580-629) & 2 & 4.1 & 49 & $9-153$ & - & 0.3 & $\cdot$ & $\cdot$ & 2 & 4.4 & 45 & $8-142$ \\
\hline Accidents and violence $(800-999)$ & 21 & 14.7 & 143 & $96-205$ & 1 & 1.0 & 96 & $5-456$ & 22 & 15.8 & 140 & $94-199$ \\
\hline III-defined conditions $(780-799)$ & 10 & $\cdot$ & $\cdot$ & $\cdot$ & 2 & · & $\cdot$ & $\cdot$ & 12 & $\cdot$ & · & $\cdot$ \\
\hline All causes $(001-999)$ & 250 & 297.6 & 84 & $76-93$ & 20 & 25.3 & 79 & $52-115$ & 270 & 322.9 & 84 & $76-92$ \\
\hline
\end{tabular}

a Code of the International Classification of Diseases, IX revision, in parentheses. 
Table 4. Cancer mortality of the service station attendants from the Latium region $(1981-1992) .(O=$ observed deaths, $E=e x-$ pected deaths, SMR = standardized mortality ratio, $90 \% \mathrm{Cl}=90 \%$ confidence interval)

\begin{tabular}{|c|c|c|c|c|c|c|c|c|c|c|c|c|}
\hline \multirow{2}{*}{ Cause of deatha } & \multicolumn{4}{|c|}{ Men } & \multicolumn{4}{|c|}{ Women } & \multicolumn{4}{|c|}{ Total } \\
\hline & 0 & $E$ & SMR & $90 \% \mathrm{Cl}$ & 0 & $\mathbf{E}$ & SMR & $90 \% \mathrm{Cl}$ & 0 & $E$ & SMR & $90 \% \mathrm{Cl}$ \\
\hline Oral cavity and pharynx $(140-9)$ & 1 & 2.7 & 38 & $2-179$ & - & 0.1 & . & · & 1 & 2.7 & 37 & $2-174$ \\
\hline Digestive organs $(150-9)$ & 22 & 31.9 & 69 & $47-98$ & 1 & 3.0 & 33 & $2-157$ & 23 & 34.9 & 66 & $45-93$ \\
\hline $\begin{array}{l}\text { Esophagus (150) } \\
\text { Stomach (151) } \\
\text { Colon (153) } \\
\text { Liver (155) } \\
\text { Pancreas (157) }\end{array}$ & $\begin{array}{l}4 \\
6 \\
6 \\
3 \\
2\end{array}$ & $\begin{array}{l}1.7 \\
9.3 \\
5.3 \\
5.8 \\
3.6\end{array}$ & $\begin{array}{r}241 \\
64 \\
113 \\
52 \\
55\end{array}$ & $\begin{array}{l}82-551 \\
28-127 \\
49-224 \\
14-135 \\
10-173\end{array}$ & $\frac{-}{-}$ & $\begin{array}{l}0.1 \\
0.7 \\
0.6 \\
0.5 \\
0.3\end{array}$ & 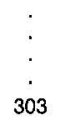 & $\begin{array}{c}\dot{i} \\
15-1438\end{array}$ & $\begin{array}{l}4 \\
6 \\
6 \\
3 \\
3\end{array}$ & $\begin{array}{r}1.7 \\
10.0 \\
5.9 \\
6.2 \\
4.0\end{array}$ & $\begin{array}{r}234 \\
60 \\
102 \\
48 \\
76\end{array}$ & $\begin{array}{l}80-535 \\
26-118 \\
44-201 \\
13-125 \\
21-195\end{array}$ \\
\hline Respiratory organs $(160-5)$ & 33 & 37.0 & 89 & $65-119$ & - & 0.9 & · & $\cdot$ & 33 & 37.9 & 87 & $64-117$ \\
\hline $\begin{array}{l}\text { Larynx (161) } \\
\text { Lung (162) }\end{array}$ & $\begin{array}{r}3 \\
29\end{array}$ & $\begin{array}{r}2.9 \\
32.3\end{array}$ & $\begin{array}{r}105 \\
87\end{array}$ & $\begin{array}{l}29-272 \\
64-123\end{array}$ & $\overline{-}$ & $\begin{array}{l}0.0 \\
0.8\end{array}$ & ; & $\dot{r}$ & $\begin{array}{r}3 \\
29\end{array}$ & $\begin{array}{r}2.9 \\
34.1\end{array}$ & $\begin{array}{r}105 \\
85\end{array}$ & $\begin{array}{l}29-270 \\
61-116\end{array}$ \\
\hline Connective tissue (171) & 1 & 0.2 & 588 & $30-2791$ & - & 0.0 & . & · & 1 & 0.2 & 526 & $27-2497$ \\
\hline Melanoma (172) & 1 & 0.7 & 137 & $7-650$ & - & 0.1 & . & $\cdot$ & 1 & 0.8 & 123 & $6-586$ \\
\hline Breast (174-5) & - & 0.0 & $\cdot$ & $\cdot$ & 2 & 1.9 & 104 & $18-328$ & 2 & 2.0 & 102 & $18-321$ \\
\hline Uterus $(179-80,182)$ & - & $\cdot$ & $\cdot$ & $\cdot$ & 1 & 0.7 & 154 & $8-730$ & 1 & 0.7 & 154 & $8-730$ \\
\hline Prostate (185) & 2 & 5.3 & 38 & $7-119$ & $\cdot$ & - & . & $\cdot$ & 2 & 5.3 & 38 & $7-119$ \\
\hline Bladder (188) & 6 & 4.9 & 122 & $53-242$ & - & 0.1 & $\cdot$ & · & 6 & 5.0 & 120 & $52-236$ \\
\hline Kidney (189) & - & 2.3 & $\cdot$ & $\cdot$ & - & 0.1 & . & . & - & 2.4 & . & $\cdot$ \\
\hline Nervous system (190-2) & 5 & 2.6 & 195 & $77-411$ & 1 & 0.3 & 400 & $20-1898$ & 6 & 2.8 & 214 & $93-421$ \\
\hline Site unspecified (195-9) & 2 & 3.7 & 54 & $10-169$ & - & 0.4 & $\cdot$ & $\cdot$ & 2 & 4.1 & 48 & $9-152$ \\
\hline Lymphohematopoietic (200-8) & 5 & 6.7 & 75 & $29-157$ & - & 0.7 & . & . & 5 & 7.3 & 68 & $27-143$ \\
\hline $\begin{array}{l}\text { Non-Hodgkin's lymphoma }(200,202) \\
\text { Leukemia }(204-8)\end{array}$ & $\begin{array}{l}3 \\
2\end{array}$ & $\begin{array}{l}1.7 \\
3.3\end{array}$ & $\begin{array}{r}173 \\
61\end{array}$ & $\begin{array}{l}47-448 \\
11-192\end{array}$ & - & $\begin{array}{l}0.2 \\
0.3\end{array}$ & $\dot{r}$ & $\dot{r}$ & $\begin{array}{l}3 \\
2\end{array}$ & $\begin{array}{l}1.9 \\
3.6\end{array}$ & $\begin{array}{r}158 \\
56\end{array}$ & $\begin{array}{l}43-408 \\
10-175\end{array}$ \\
\hline
\end{tabular}

a Code of the International Classification of Diseases, IX revision, in parentheses.

Table 5. Mortality of the attendants of small service stations from the Latium region (1981-1992) by selected causes of death. $(\mathrm{O}=$ observed deaths, $\mathrm{E}=$ expected deaths, $\mathrm{SMR}=$ standardized mortality ratio, $90 \% \mathrm{Cl}=90 \%$ confidence interval).

\begin{tabular}{|c|c|c|c|c|c|c|c|c|c|c|c|c|}
\hline \multirow{2}{*}{ Cause of death } & \multicolumn{4}{|c|}{ Men } & \multicolumn{4}{|c|}{ Women } & \multicolumn{4}{|c|}{ Total } \\
\hline & 0 & $E$ & SMR & $90 \% \mathrm{Cl}$ & 0 & $\mathbf{E}$ & SMR & $90 \% \mathrm{Cl}$ & 0 & $E$ & SMR & $90 \% \mathrm{Cl}$ \\
\hline Malignant neoplasms (140-208) & 60 & 68.6 & 87 & $70-108$ & 3 & 5.99 & 51 & $14-133$ & 63 & 74.4 & 85 & $68-104$ \\
\hline $\begin{array}{l}\text { Esophagus (150) } \\
\text { Colon (153) } \\
\text { Pancreas (157) } \\
\text { Larynx (161) } \\
\text { Lung (162) } \\
\text { Connective tissue (171) } \\
\text { Melanoma (172) } \\
\text { Bladder ( }(88) \\
\text { Kidney (189) } \\
\text { Nervous system (190-2) } \\
\text { Lymphohematopoietic (200-8) }\end{array}$ & $\begin{array}{r}4 \\
5 \\
2 \\
3 \\
22 \\
1 \\
1 \\
4 \\
-4 \\
4\end{array}$ & $\begin{array}{r}1.1 \\
3.7 \\
2.5 \\
2.0 \\
22.7 \\
0.1 \\
0.5 \\
3.5 \\
1.6 \\
1.7 \\
4.6\end{array}$ & $\begin{array}{r}351 \\
136 \\
80 \\
153 \\
97 \\
833 \\
204 \\
116 \\
6 \\
233 \\
44\end{array}$ & $\begin{array}{c}120-803 \\
54-286 \\
14-252 \\
42-396 \\
63-138 \\
43-3953 \\
10-968 \\
40-265 \\
7 \\
79-532 \\
8-138\end{array}$ & $\begin{array}{l}- \\
-1 \\
- \\
- \\
- \\
- \\
-\end{array}$ & $\begin{array}{l}0.0 \\
0.4 \\
0.2 \\
0.0 \\
0.5 \\
0.0 \\
0.0 \\
0.1 \\
0.1 \\
0.2 \\
0.4\end{array}$ & $\begin{array}{c}: \\
476 \\
\vdots \\
: \\
\dot{.} \\
625\end{array}$ & $\begin{array}{c}24-2259 \\
: \\
: \\
: \\
32-2965\end{array}$ & $\begin{array}{r}4 \\
5 \\
3 \\
3 \\
22 \\
1 \\
1 \\
4 \\
5 \\
2\end{array}$ & $\begin{array}{r}1.2 \\
4.1 \\
2.7 \\
2.0 \\
23.3 \\
0.1 \\
0.6 \\
3.5 \\
1.6 \\
1.9 \\
5.0\end{array}$ & $\begin{array}{r}342 \\
123 \\
111 \\
152 \\
95 \\
769 \\
182 \\
113 \\
\cdot \\
266 \\
40\end{array}$ & $\begin{array}{c}117-782 \\
48-258 \\
30-286 \\
42-394 \\
64-135 \\
39-3649 \\
9-863 \\
39-259 \\
\cdot \\
105-559 \\
7-126\end{array}$ \\
\hline $\begin{array}{l}\text { Non-Hodgkin's lymphoma }(200,202) \\
\text { Leukemia }(204-8)\end{array}$ & $\frac{2}{-}$ & $\begin{array}{l}1.2 \\
2.3\end{array}$ & 171 & $30-538$ & - & $\begin{array}{l}0.1 \\
0.2\end{array}$ & $\dot{.}$ & $\dot{.}$ & $\underline{2}$ & $\begin{array}{l}1.3 \\
2.5\end{array}$ & $\begin{array}{c}156 \\
.\end{array}$ & $28-492$ \\
\hline Blood $(280-289)$ & 1 & 0.6 & 182 & $9-863$ & 1 & 0.1 & 1667 & $85-7907$ & 2 & 0.6 & 323 & $57-1015$ \\
\hline Nervous system $(320-359)$ & 1 & 3.1 & 33 & $2-155$ & - & 0.3 & . & · & 1 & 3.4 & 30 & $2-140$ \\
\hline Circulatory system $(390-459)$ & 70 & 80.7 & 87 & $70-106$ & 2 & 6.5 & 31 & $5-97$ & 72 & 87.2 & 83 & $67-100$ \\
\hline Respiratory system $(460-519)$ & 7 & 13.9 & 50 & $24-95$ & - & 0.7 & . & · & 7 & 14.6 & 48 & $23-90$ \\
\hline Accidents and violence $(800-999)$ & 13 & 9.9 & 132 & $78-209$ & - & 0.7 & . & - & 13 & 10.6 & 123 & $73-195$ \\
\hline All causes $(001-999)$ & 178 & 207.2 & 86 & $76-97$ & 13 & 16.9 & 77 & $45-122$ & 191 & 224.2 & 85 & $75-96$ \\
\hline
\end{tabular}

a Code of the International Classification of Diseases, $I X$ revision, in parentheses.

cesses of blood diseases, soft tissue sarcoma, and melanoma were concentrated into this subcohort (table 5). For these workers, furthermore, an increased risk of laryngeal cancer was recorded. The excess risk of non-Hodgkin's lymphoma was, however, almost equally distributed among the two subcohorts (tables 5 and 6). Attendants of large service stations, on the other hand, showed increased risks of bladder cancer, leukemia, and nervous system diseases (table 6).

\section{Discussion}

This study represents the first workplace-based cohort of filling station attendants. In fact, epidemiologic investigations of this occupational group are particularly difficult to carry out because managers, although directly involved in refueling, are self-employed workers, attendants are scattered among a large number of very small stations, and neither of these groups are generally subject to any form of centralized personnel record-keeping requirements. 
Table 6. Mortality of the attendants of large service stations from the Latium region (1981-1992) by selected causes of death. $(\mathrm{O}=$ observed deaths, $\mathrm{E}=$ expected deaths, $\mathrm{SMR}=$ standardized mortality ratio, $90 \% \mathrm{Cl}=90 \%$ confidence interval).

\begin{tabular}{|c|c|c|c|c|c|c|c|c|c|c|c|c|}
\hline \multirow{2}{*}{ Cause of deatha } & \multicolumn{4}{|c|}{ Men } & \multicolumn{4}{|c|}{ Women } & \multicolumn{4}{|c|}{ Total } \\
\hline & 0 & E & SMR & $90 \% \mathrm{Cl}$ & 0 & $E$ & SMR & $90 \% \mathrm{Cl}$ & 0 & $\mathbf{E}$ & SMR & $90 \% \mathrm{Cl}$ \\
\hline Malignant neoplasms (140-208) & 18 & 31.0 & 58 & $37-86$ & 2 & 3.0 & 67 & $12-211$ & 20 & 34.0 & 59 & $39-85$ \\
\hline $\begin{array}{l}\text { Esophagus (150) } \\
\text { Colon (153) } \\
\text { Pancreas (157) } \\
\text { Larynx (161) } \\
\text { Lung (162) } \\
\text { Connective tissue (171) } \\
\text { Melanoma (172) } \\
\text { Bladder (188) } \\
\text { Kidney (189) } \\
\text { Nervous system (190-2) } \\
\text { Lymphohematopoietic (200-8) }\end{array}$ & $\begin{array}{l}\overline{1} \\
\overline{-} \\
\frac{7}{-} \\
\frac{2}{2} \\
\frac{1}{3}\end{array}$ & $\begin{array}{r}0.5 \\
1.6 \\
1.1 \\
0.9 \\
10.5 \\
0.1 \\
0.3 \\
1.4 \\
0.7 \\
0.9 \\
2.1\end{array}$ & $\begin{array}{c}\cdot \\
62 \\
\cdot \\
\cdot \\
67 \\
\cdot \\
\dot{\cdot} \\
139 \\
\cdot \\
116 \\
142\end{array}$ & $\begin{array}{c}3-293 \\
\cdot \\
31-125 \\
\cdot \\
25-437 \\
\cdot \cdot \\
6-552 \\
39-366\end{array}$ & $\begin{array}{l}- \\
- \\
- \\
- \\
- \\
- \\
-\end{array}$ & $\begin{array}{l}0.0 \\
0.2 \\
0.1 \\
0.0 \\
0.3 \\
0.0 \\
0.0 \\
0.1 \\
0.1 \\
0.1 \\
0.2\end{array}$ & 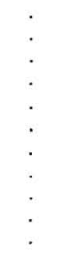 & 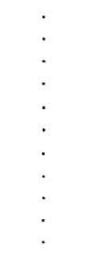 & $\begin{array}{l}- \\
- \\
- \\
-7 \\
- \\
\frac{2}{1} \\
3\end{array}$ & $\begin{array}{r}0.5 \\
1.8 \\
1.3 \\
0.9 \\
10.8 \\
0.1 \\
0.3 \\
1.5 \\
0.8 \\
0.9 \\
2.3\end{array}$ & $\begin{array}{c}5 \\
55 \\
\cdot \\
\cdot \\
65 \\
\cdot \\
\cdot \\
134 \\
\cdot \\
106 \\
128\end{array}$ & $\begin{array}{c}3-261 \\
\cdot \\
30-122 \\
\cdot \\
\cdot \\
24-423 \\
\cdot \\
5-505 \\
35-331\end{array}$ \\
\hline $\begin{array}{l}\text { Non-Hodgkin's lymphoma }(200,202) \\
\text { Leukemia }(204-8)\end{array}$ & $\begin{array}{l}1 \\
2\end{array}$ & $\begin{array}{l}0.6 \\
1.0\end{array}$ & $\begin{array}{l}179 \\
196\end{array}$ & $\begin{array}{r}9-847 \\
35-617\end{array}$ & - & $\begin{array}{l}0.1 \\
0.1\end{array}$ & $\dot{.}$ & $\dot{.}$ & $\begin{array}{l}1 \\
2\end{array}$ & $\begin{array}{l}0.6 \\
1.1\end{array}$ & $\begin{array}{l}161 \\
177\end{array}$ & $\begin{array}{r}8-765 \\
31-557\end{array}$ \\
\hline Blood $(280-289)$ & - & 0.3 & $\cdot$ & $\cdot$ & - & 0.0 & . & . & - & 0.3 & $\cdot$ & $\cdot$ \\
\hline Nervous system $(320-359)$ & 3 & 1.3 & 231 & $63-596$ & - & 0.2 & . & · & 3 & 1.5 & 204 & $56-527$ \\
\hline Circulatory system $(390-459)$ & 27 & 34.0 & 80 & $56-110$ & 4 & 3.1 & 129 & $44-296$ & 31 & 37.1 & 84 & $61-113$ \\
\hline Respiratory system $(460-519)$ & 7 & 5.5 & 127 & $59-238$ & - & 0.3 & $\cdot$ & $\cdot$ & 7 & 5.9 & 120 & $56-225$ \\
\hline Accidents and violence $(800-999)$ & 8 & 4.9 & 165 & $82-297$ & 1 & 0.3 & 294 & $15-1395$ & 9 & 5.2 & 173 & $90-302$ \\
\hline All causes $(001-999)$ & 72 & 90.4 & 80 & $65-97$ & 7 & 8.3 & 84 & $39-158$ & 79 & 98.8 & 80 & $66-94$ \\
\hline
\end{tabular}

a Code of the International Classification of Diseases, IX revision, in parentheses.

The following three issues are worth discussing: (i) the completeness of the cohort in relation to available sources which catalogue workers employed in this trade, (ii) a comparison of our findings with results from available relevant studies, (iii) and, finally, the major shortcomings of this study.

In the 1981 Italian census, the economic sector "retail sales of fuels and lubricants" listed 32034 local units and 60869 workers. More than $50 \%$ of the work force consisted of self-employed workers $(\mathrm{N}=32606), 20 \%$ were employed family members $(\mathrm{N}=12439), 4 \%$ were salaried clerks $(\mathrm{N}=2470)$, and $22 \%$ were workmen $(\mathrm{N}=13354)(10)$. Within the Latium region, according to the census (11), there were 3077 service stations, employing 5784 workers. Of these, 3018 were self-employed workers $(54 \%), 1040$ were employed family members $(18 \%)$, 172 were salaried clerks (3\%), and 1464 were workmen $(25 \%)$. The cohort data source recorded a higher number of service stations $(\mathrm{N}=3272)$ one year earlier, a finding compatible with normal market fluctuations.

We studied, therefore, about half of the whole work force employed in gasoline service stations in the region, namely, the self-employed managers, excluding family and salaried workers. The mortality experience of these populations might be different from that of the one under study. However, as most of the cohort members declared full-time employment [ 2169 out of 2379 with available information $(91.2 \%)]$ and the majority of their stations employed one or two workers [ 1827 out of 2581 with available information $(70.8 \%)$ ], we deemed that our "filling station attendants" were directly involved in refueling.

We found excess risks, although not statistically significant, for blood diseases, esophageal cancer, nervous system cancer, and non-Hodgkin's lymphoma in the whole cohort. Moreover, an increase in the SMR values for these causes of death was found for the managers of small stations, along with an excess risk for laryngeal cancer. Managers of large stations, on the other hand, showed increased risks for bladder cancer, leukemia, and nervous system diseases. The exposure profile of small station workers can be the most easily characterized in terms of gasoline vapors and exhausts, while attendants in large stations were involved in other tasks besides refueling, such as mechanical, electrical, and tire repairing jobs. This difference could explain, at least partially, the different patterns of mortality observed.

Previous findings relating to risk excesses among filling station attendants stem from surveillance systems of occupational mortality or cancer incidence. Auto service and gasoline station workers in California (1959-1961) showed significantly elevated proportional mortality ratios (PMR) for oral cavity, lung, and testicular cancers (12). Among the service station owners and attendants in Washington State (1950-1979) elevated PMR values were found for cancers of the oral cavity, kidney, bladder, and testis and for aplastic anemia (13). In Massachusetts (1971-1973) a small increase in the PMR for leukemia was found for auto mechanics and gasoline station attendants (14). Service station workers in New Hampshire (1975-1985) showed increased mortality for leukemia, suicide, emphysema, and mental and psychoneurotic conditions (15). Owners of filling stations in Denmark, as defined on the basis of the 1970 Danish census, showed an increased incidence of kidney cancer over the period 1970-1980 (16). They were also found to be at increased risk of dying from respiratory cancers over the period 1970-1987 (17). A significantly 
increased standardized incidence ratio (SIR) for acute myeloid leukemia was found among Swedish gasoline station attendants, as of the 1970 census, followed-up over the period 1971-1984 (18). In the Montreal multisite, multiple-exposure case-referent study, exposure to automotive gasoline was associated with a significantly increased risk of stomach cancer, with a dose-response effect (19), while exposure to gasoline exhausts proved to be associated with excess risk of rectal cancer, also with a dose-response effect (20).

Further evidence about increased risk at different cancer sites in association with exposures relevant to filling station attendants (benzene, hydrocarbons, fuels, vehicle exhausts, and combustion products) was found in case-referent studies on leukemia (2126), multiple myeloma (27-28), and esophageal (29), laryngeal (30), bladder (31-35), kidney (19, $36-42)$ and lung (43-46) cancers. An excess risk of developing soft-tissue sarcomas for long-term occupational exposure to benzene and other solvents was reported in a case-referent study from northeastern Italy (47). Increasing risk with increasing level of exposure to benzene was found in a casereferent study in the United States on non-Hodgkin's lymphoma (48). Excess risks for brain tumors have been associated with employment in petroleum refining (49). Finally, increased risks of kidney cancer, leukemia, and cancers of the larynx and prostate were found in a cohort of 23306 British oil distribution workers (50).

Our findings essentially confirm previously reported excess risks, with the remarkable exclusion of kidney cancer, for which no death was recorded. The deficit in mortality from all causes, cardiovascular diseases, and respiratory diseases could be ascribed to the relatively low duration of the follow-up, and to the combination of factors generally referred to as the "healthy worker effect." In spite of an increase in mortality from lung cancer, as reported in association with exposure to exhausts from engines operating on diesel fuel (3), we observed an SMR below the null value. The observed excesses of blood and nervous system diseases deserve attention, in view of the exposure to the hematological and neurological toxicants present in gasoline vapors.

A major drawback is that the power of this study, for most of the causes of interest, was low and the duration of the follow-up might have been insufficient for cancers that have a long induction period. Furthermore, because of the lack of information on employment termination dates, we did not examine the observed excess risks by length of employment, a usual proxy for duration of exposure.

Lack of information about smoking habits and alcohol consumption is undoubtedly a weakness of this study. Nevertheless, mortality due to tobacco- and alcohol-related causes of death (lung cancer, respiratory diseases, and digestive diseases, particularly cirrhosis of the liver) was not increased in the co- hort. Alcohol consumption is of major concern in relation to the observed increased risk of esophageal tumors. However, in the sample of current filling station attendants (9), only $27.3 \%$ of the subjects drank one glass of wine or more per day. In the Italian population in 1983, among men aged $30 \longrightarrow 60$ years, there were $52.5 \%$ drinkers of a quarter liter or more of wine (51). Therefore, confounding from alcohol consumption, in respect of the association between exposure to gasoline vapors and esophageal cancer, seems unlikely.

In conclusion, filling station attendants are exposed to gasoline vapors containing aromatic hydrocarbons, including benzene. This group of workers seems at risk of cancer at various sites. The observed increased risks are consistent with the hazards to which they are exposed. Due to the power limitations of this study, a precise estimate of the risk for many causes of death is not achievable. Further cohort studies of greater size are warranted.

\section{Acknowledgments}

The technical assistance of Ms P Dell'Armi, Mr V Goffredo, and Ms M Tassi is gratefully acknowledged.

The study was partially funded by the Italian Ministry of Labour (contract 404/1990) and by the European Economic Community (contract EV5VCT92-0221).

Preliminary results of this study were presented at the 9th International Symposium on Epidemiology in Occupational Health in Cincinnati, Ohio, on 2325 September 1992.

\section{References}

1. Anonymous. Toxicology update: gasoline. J Appl Toxicol 1989;9:203-10.

2. International Agency for Research on Cancer (IARC). Occupational exposures in petroleum refining; crude oil and major petroleum fuels. Lyon: IARC, 1989. IARC monographs on the evaluation of carcinogenic risks to humans, vol 45 .

3. International Agency for Research on Cancer (IARC). Diesel and gasoline engine exhausts and some nitroarenes. Lyon: IARC, 1989. IARC monographs on the evaluation of carcinogenic risks to humans, vol 46 .

4. Mehlman MA. Dangerous properties of petroleum refining products: carcinogenicity of motor fuels (gasoline). Teratogen Carcinog Mutagen 1990;10:399-408.

5. Infante PF, Schwartz E, Cahill R. Benzene in petrol: a continuing hazard [letter]. Lancet 1990;336:814 5 .

6. Mehlman MA. Benzene health effects: unanswered questions still not addressed [commentary]. Am J Ind Med 1991;20:707-11.

7. Lagorio S, Forastiere F, Michelozzi P, Perucci CA, Altavista P, Costa G, Vigotti MA. Accertamento delle cause di morte in studi di follow-up: confronto di procedure utilizzabili in Italia [Cause of death ascertainment in follow-up studies: comparison of methods available in Italy]. Epidemiol Prevenzione 1987;31: $57-61$. English summary. 
8. Marsh GM Preininger M, Ehland JJ. Occupational cohort mortality analysis program (OCMAP PC). Pittsburgh, PA: University of Pittsburgh, 1989.

9. Lagorio S, Forastiere F, Iavarone I, Vanacore N, Fuselli S, Carere A. Exposure assessment in a historical cohort of filling station attendants. Int $\mathrm{J}$ Epidemiol 1993;22 suppl 2:S51-6.

10. Istituto Centrale di Statistica (ISTAT). $6^{\circ}$ Censimento generale dell'industria, del commercio, dei servizi e dell'artigianato. 26 Ottobre 1981. Vol. II. Dati sulle caratteristiche strutturali delle imprese e delle unità locali [ 6 th census of industry, trade and services. October 26th, 1981, vol 3]. Rome: ISTAT, 1985.

11. Istituto Centrale di Statistica (ISTAT). $6^{\circ}$ Censimento generale dell'industria, del commercio, dei servizi e dell'artigianato. 26 Ottobre 1981. Vol. II. Dati sulle caratteristiche strutturali delle imprese e delle unità locali [6th census of industry, trade and services. October 26th, 1981, vol 2-12 (Latium region)]. Rome: ISTAT, 1985.

12. Petersen GR, Milham S Jr. Occupational mortality in the state of California 1959-61. Cincinnati, OH: National Institute for Occupational Safety and Health, 1980. DHEW, NIOSH publication no 80-104.

13. Milham S Jr. Occupational mortality in Washington State, 1950-1979. Cincinnati, OH; National Institute for Occupational Safety and Health, 1983. DHEW, NIOSH publication no 83-116.

14. Dubrow R, Wegman DH. Occupational characteristics of cancer victims in Massachusetts 1971-1973. Cincinnati, $\mathrm{OH}$; National Institute for Occupational Safety and Health, 1984. DHEW, NIOSH publication no $84-109$.

15. Schwartz E. PMR analysis of automobile mechanics and gasoline service station workers in New Hampshire. Am J Ind Med 1987;12:91-9.

16. Lynge E, Thygesen L. Occupational cancer in Denmark: cancer incidence in the 1970 census population. Scand J Work Environ Health 1990;16 suppl 2:1-35.

17. Grandjean $P$, Andersen $O$. Lung cancer in filling station attendants. Am J Ind Med 1991;20:763-8.

18. Jakobsson R, Ahlbom A, Bellander T, Lundberg I. Acute myeloid leukemia among petrol station attendants. Arch Environ Health 1993;48:255-9.

19. Siemiatycki J, Dewar R, Nadon L, Gérin M, Richardson L, Wacholder S. Associations between several sites of cancer and twelve petroleum derived liquids: results from a case-referent study in Montreal. Scand J Work Environ Health 1987;13:493-504.

20. Siemiatycki J, Gérin M, Stewart P, Nadon L, Dewar $\mathrm{R}$, Richardson L. Associations between several sites of cancer and ten types of exhaust and combustion products: results from a case-referent study in Montreal. Scand J Work Environ Health 1988;14:79—90.

21. Brandt L, Nilsson PG, Mitelman F. Occupational exposure to petroleum products in men with acute nonlymphocytic leukemia. Br Med J 1978;35:553.

22. Flodin $U$, Fredriksson $M$, Persson $B$, Axelson $O$. Chronic lymphatic leukemia and engine exhausts, fresh wood, and DDT: a case-referent study. Br J Ind Med 1988;45:33-8.

23. Bastuji-Garin S, Richardson S, Zittoun R. Facteurs de risque professionnels dans les leucémies aigues. Arch Mal Prof 1990;51:149-55.

24. Lindquist R, Nilsson B, Eklund G, Gahrton G. Acute leukemia in professional drivers exposed to gasoline and diesel. Eur J Hematol 1991;47:98 - 103.

25. Pasqualetti P, Casale R, Colantonio D, Collacciani A. Occupational risk for hematological malignancies. Am J Hematol 1991;38:147-9.

26. Ciccone G, Mirabelli D, Levis A, Gavarotti P, RegeCambrin G, Davico L, Vineis P. Myeloid leukemia and myelodysplastic syndromes: chemical exposure, histologic subtype and cytogenetics in a case-control study. Cancer Genet Cytogenet 1993;68:135-9.

27. Flodin U, Fredriksson M, Persson B. Multiple myeloma and engine exhausts, fresh wood, and creosote: a case-referent study. Am J Ind Med 1987;12:519-29.

28. Heineman EF, Olsen JH, Pottern LM, Gomez M, Raffn E, Blair A. Occupational risk factors for multiple myeloma among Danish men. Cancer Causes Control 1992; 3:555-68.

29. Gustavsson P, Evanoff B, Hogstedt C. Increased risk of esophageal cancer among workers exposed to combustion products. Arch Environ Health 1993;48:2435.

30. Ahrens W, Jockel KH, Patzak W, Elsner G. Alcohol, smoking, and occupational factors in cancer of the larynx: a case-control study. Am J Ind Med 1991;20: $477-93$.

31. Schoenberg JB, Stemhagen A, Mogielnicki AP, Altman R, Abe T, Mason TJ. Case-control study of bladder cancer in New Jersey: I. occupational exposures in white males. JNCI 1984;72:973-81.

32. Hoar SK, Hoover R. Truck driving and bladder cancer mortality in rural New England. JNCI 1985;74: $771-4$.

33. Claude JC, Frentzel-Beyme RR, Kunze E. Occupation and risk of cancer of the lower urinary tract among men: a case-control study. Int J Cancer 1988;41:3719.

34. Risch HA, Burch JD, Miller AB, Hill GB, Steele R, Howe GR. Occupational factors and the incidence of cancer of the bladder in Canada. $\mathrm{Br} \mathrm{J}$ Ind Med $1988 ; 45: 361-7$

35. Steineck G, Plato N, Gerhardsson M, Norell SE Hogstedt C. Increased risk of urothelial cancer in Stockholm during 1985-87 after exposure to benzene and exhausts. Int J Cancer 1990;45:1012-7.

36. McLaughlin JK, Mandel JS, Blot WJ, Schuman LM, Mehl ES, Fraumeni JF. A population-based case-control study of renal cell carcinoma. JNCI 1984;72:27584.

37. McLaughlin JK, Blot WJ, Mehl ES, Stewart PA, Venable FS, Fraumeni JF Jr. Petroleum-related employment and renal cell cancer. J Occup Med 1985;27: $672-4$.

38. Domiano SF, Vena JE, Swanson MK. Gasoline exposure, smoking and kidney cancer [letter]. J Occup Med $1985 ; 27: 398$ - 9 .

39. Jensen OM, Knudsen JB, McLaughlin JK, Sorensen BL. The Copenhagen case-control study of renal pelvis and ureter cancer: role of smoking and occupational exposures. Int J Cancer 1988;41:557-61.

40. Kadamani S, Asal NR, Nelson RY. Occupational hydrocarbon exposure and risk of renal cell carcinoma. Am J Ind Med 1989;15:131-41.

41. Partanen T, Heikkila P, Hernberg S, Kauppinen T, Moneta G, Ojajarvi A. Renal cell cancer and occupational exposure to chemical agents. Scand J Work Environ Health $1991 ; 17: 231-9$.

42. McLaughlin JK, Gao Y, Gao R, Zheng W, Ji B, Blot WJ. Risk factors for renal-cell cancer in Shangai, China. Int J Cancer 1992;52:562 - 5.

43. Coggon D, Pannett B, Acheson ED. Use of job-exposure matrix in an occupational analysis of lung and bladder cancers on the basis of death certificates. JNCI 1984;72:61-5.

44. Hinds MW, Kolonel LN, Lee J. Application of a jobexposure matrix to a case-control study of lung cancer. JNCI 1985;75:193-7.

45. Garshick E, Schenker MB, Munoz A, Segal M, Smith TJ, Woskie SR, et al. A case-control study of lung cancer and diesel exhaust exposure in railroad workers. Am Rev Respir Dis 1987;135:1242-8.

46. Hayes RB, Thomas T, Siverman DT, Vineis P, Blot WJ, Mason TJ, et al. Lung cancer in motor exhaustrelated occupations. Am J Ind Med 1989;16:685-95. 
47. Serraino D, Franceschi S, La Vecchia C, Carbone A. Occupation and soft-tissue sarcoma in north-eastern Italy. Cancer Causes Control 1992;3:25-30.

48. Blair A, Linos A, Stewart PA, Burmeister LF, Gibson $R$, Everett $G$, et al. Evaluation of risks for nonHodgkin's lymphoma by occupation and industry exposures from a case-control study. Am J Ind Med 1993;23:301-12.

49. Moss AR. Occupational exposure and brain tumors. J Toxicol Environ Health 1985;16:703-11.

50. Rushton L. Further follow up of mortality in a Unit- ed Kingdom oil distribution centre cohort. $\mathrm{Br} \mathbf{J}$ Ind Med 1993;50:561—9.

51. Istituto Centrale di Statistica (ISTAT). Indagine statistica sulle condizioni di salute della popolazione e sul ricorso ai servizi sanitari. Novembre 1983 [Health survey of a sample of Italian citizens. November 1983]. Rome: ISTAT, 1986. Note e Relazioni, no 1.

Received for publication: 20 January 1994 